\title{
PRIVATE FORESTRY
}

By

HENRY S. GRAVES

Forester, Forest Service

$\nabla$

Address before the New England Forestry Conference, Boston, February 24, 1919

\section{UNITED STATES DEPARTMENT OF AGRICULTURE}

\section{CIRCULAR 129}

OFFICE OF THE SECRETARY 
${ }^{52} 0^{8^{5}}$

\section{हath 50}

Agric.-Forestry. Main Librery

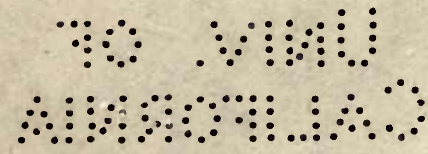




\section{PRIVATE FORESTRY.}

[Address by Henry S. Graves before the New England Forestry Conference, Boston, February 24, 1919.]

\section{IMPORTANCE OF PRIVATE FORESTS.}

$7 \mathrm{HE}$ emphasis placed on the public forests in recent years has 1 tended to throw into the background the problems of our private forests. The very magnitude of the National Forest enterprise has created in the minds of many people the impression that the problem of forestry in this country is already on the way to definite solution. In point of fact only certain initial steps have been taken; the most difficult problem, that of the protection and right handling of forests privately owned, is still before us. The importance of the private forests to our country is evident when one considers that 97 per cent of the timber and other wood products used in the United States is obtained from them. Less than 2 per cent of the sawmills of the country are operating on public forests. Private owners hold four-fifths of the standing timber of the country, and it is the best and most accessible timber. Nearly the entire supply of certain important commercial species is in private ownership, such as eastern white pine and spruce, southern pine, cypress, redwood, and most of the hardwoods.

\section{DIFFICULTIES ENCOUNTERED IN MEETING WAR DEMANDS FOR TIMBER.}

The experience of the war called sharp attention to the condition of our remaining timber supplies. The bulk of the material for general construction was obtained from a few large centers of original forest, often involving long rail hauls and high cost. Extreme difficulties were encountered in obtaining promptly an adequate supply of specialized products, like some of the high-grade hardwoods. If the emergency had come 15 years from now we would have had very great embarrassment in obtaining even the lumber needed for general construction, except at great sacrifice in time, cost, and 
crowding of the railroads. Most of the lumber would have come from the Pacific Coast. We may not expect a repetition of such a grave emergency as we have just passed through, but we would be unwise indeed if we failed to recognize that the sources of timber supply upon which we have relied are being greatly depleted, with far-reaching economic and industrial consequences.

\section{WANING SUPPLIES OF VIRGIN TIMBER.}

Many people are deluding themselves with the idea that we do not need to concern ourselves with regard to forests because of large virgin supplies which still exist in the Pacific Northwest, the Inland Empire, and California. I have even heard it suggested that if we should use up or destroy all of the forests in the United States, there are very considerable quantities of wood supplies in the great river valleys of Brazil and other South American countries.

Eeaders of the southern pine manufacturers state that the bulk of the original supplies of yellow pine in the South will be exhausted in 10 years and that within the next five to seven years more than 3,000 manufacturing plants will go out of existence. This is an exceedingly significant statement, because it means that the center of lumber production of the United States will within no long time nove to the Pacific Coast. While it does not mean that there will be an actual exhaustion of all of the timber in the South, it does mean that the competitive influence of southern pine in many markets will be withdrawn and that there will be the increase of prices that inevitably must follow such an important economic occurrence as the shift of the center of supply of a raw material one to three thousand miles.

One of the most acute problems of forest supplies is that of wood pulp, particularly the material suitable for news print. Already paper manufacturers are embarrassed for supplies. Some of our principal paper concerns have fortified themselves by purchasing large blocks of timber in Canada. Many of you are familiar with the progressive diminution of supplies in the regions like the White Mountains, where private owners are rapidly working back on the high slopes, even stripping off areas which for the general public benefit should be kept substantially intact for all time. It is my hope that we may secure sufficient public support to enable us to accelerate the acquisition by the Government of the more important remaining areas before it is too late. The claim is made that the Adirondack State Preserve should be opened to cutting because of the urgent need of supplies for the paper mills in the near future. The question of supplying the paper mills in Michigan and Wisconsin is even more acute, and it is only a question of time when those mills will have to 
import their pulp wood from a long distance or liquidate investments of great value in water power and plant and move to new sources of supplies. Partly owing to the rapid exhaustion of the old sources of wood-pulp supply and partly owing to the tariff laws of Canada, American capital is going into that country to build mills to supply this country with wood pulp and paper. Within the last 10 years new mill development for news-print manufacture in this country has almost wholly ceased, while in Canada during that time no less than 28 mills have been built, largely with American capital. It would be possible for me to describe the acute situation confronting many of the other industries that use special classes of forest products, due to the uncertainty in regard to supplies in the future. I refer to industries that use oak, hickory, cherry, yellow poplar, walnut, and ash.

Douglas fir from the Pacific coast is already coming into the New England market. This means that because of the diminishing supplies in the East the prices have risen to a point where it is possible to ship lumber 3,000 miles in competition with that produced locally. With the further reduction of home spruce supplies, the approaching exhaustion of white pine in the Lake States, and the withdrawal within a few years of southern pine as a competitive factor, the East will be turning more and more to the Pacific coast. It is estimated that the Lake States, which a few years ago were the greatest producers of timber, are to-day paying a freight bill of about $\$ 6,000,000$ a year to bring in lumber and other products from outside sources.

\section{NEW ENGLAND NO LONGER SELF-SUPPORTING IN TIMBER RESOURCES.}

About 30 years ago New England was not only self-supporting in her timber resources, but exported large quantities to other parts of the country and abroad. Within the last 15 years New England has become an importing region and looks more and more for timber supplies to the South, to the Lake States, and even to the Pacific coast. It is estimated that fully 30 per cent of all the lumber used in New England now comes from outside the region. This is in addition to the importations of large quantities of pulp wood. New England is one of the important centers for wood-using industries. Heretofore many of these industries have drawn upon local supplies. It is estimated that the annual growth in New England of forest materials that will be suitable for lumber or other higher uses is less than half of what is being cut. These are facts of vital interest to a region that has about $\$ 300,000,000$ invested in the wood and forest industries and employs in this connection over 90,000 wage earners. 


\section{CONSTRUCTIVE FOREST POLICIES OF FRANCE AND ENGLAND.}

It happens that the area of forest land in New England is about $25,000,000$ acres. This is almost the same as the forest area of France, and in many respects the character of the forest has marked points of similarity. France is producing by growth each year 50 per cent more than New England. She has for years been improving her forests and approaching a point where she can furnish most of her domestic needs. New England by progressive diminution of capital stock and failure adequately to produce forests is going in exactly the other direction, losing ground every year. Before the war France was building up her forest resources; New England has been progressively destroying hers. Before the war France was importing about $80,000,000$ cubic feet of lumber. New England's imports exceed this amount. The forest and wood-using industries of France furnished employment to over 700,000 persons, and because the forests were handled in a way to keep up production by growth this employment was permanent. It was the small industries supported from local forests that furnished employment to so many people.

England before the war felt herself quite independent in forest matters. Her large merchant marine made it possible to import from many competing countries. She did not have to practice forestry. During 1915 and 1916 the excess cost over previous years of importing forest materials was $\$ 185,000,000$. The next year she had to stop importing almost entirely. She then cut down her meager forests and park timber, and finally had to rely on France, which was supplying the needs of all the armies on the west front. England now plans a great program of reforestation. She proposes to plant up over a million acres in the next 40 years, spending during the first decade over $\$ 17,000,000$ : England does not intend again to be caught without home supplies.

\section{NEGLIGENT FOREST POLICY IN THE UNITED STATES.}

New England represents in many ways the most favorable conditions for forestry in this country. The region is naturally endowed with excellent types of forest, with valuable species, and a climate favorable for tree growth. There is a large amount of land suited only to growing trees. On account of the large number of woodusing industries, markets for forest products are excellent. Transportation for moving these products is well developed. The public sentiment regarding forestry is in advance of most other parts of the country. Yet even under these favorable conditions New England is not overcoming the destructive influences that are depleting her forest resources. 
The situation is much more serious in other sections of the country. We are still drawing upon original timber for our chief national needs. We are not providing for a proper replacement of the old stock by new forest growth. Most of the private timber is cut without any regard whatever for replacement. Destructive processes are permitted that retard or actually prevent the succession of a good forest growth. Region after region is exhausted of old supplies.

- Remnants of culled forests and patches of second growth are for the most part not being protected. We are failing to produce by growth the materials that will be needed for local industries, needed to make a large part of our land useful to the State and community, needed to prevent one part of the country becoming dependent on another far-distant part, with the inevitabe burden of high prices.

Nature is so prolific that some vegetation usually follows the initial stages of forest destruction. Occasionally, by a combination of adventitious circumstances and in spite of current methods employed, reproduction follows unrestricted cutting or even a fire of moderate proportions. More often the succeeding growth is inferior. Repeated fires and other abuse cause further deterioration, so that millions of acres of cut-over land are covered with worthless species or brush or with trees that are so crooked, slow growing, or defective that they will never yield products of value. The fact that there is some woody growth on cut-over lands gives a false impression. Very commonly it is but a screen of valueless vegetation that conceals the effects of forest abuse. Pennsylvania has its great forests of low scrub oak that, through repeated fires, have replaced a growth of valuable trees. Southern New England has thousands of acres of slow-growing, crooked sprouts of hardwoods replacing pine or thrifty hardwoods. Minnesota has hundreds of square miles of bird cherry and fireweed in place of her former wonderful white and red pine. The South has its worthless black jack oak replacing the yellow pine. The Middle West has her heavily grazed woodlots that are almost bare of young growth. California has its chaparral or brush, the effect of a destructive system of annual or periodic burning of pine forests.

Sometimes forests are wiped out by a great conflagration like that in Minnesota last fall that killed several hundred people and destroyed many million dollars' worth of property. Generally the process is slower and less spectacular, but the consequences are just as serious. Already the general effect of depleting our forest resources is being felt by wood-using industries and the consumers of lumber. Hundreds of communities are suffering because the resource supporting their chief industry has been exhausted. Sawmills and 
wood-working establishments close, subsidiary industries can no longer exist, the population moves away, farms are abandoned, roads and other public improvements deteriorate, and whole townships and even counties are impoverished. A few individuals may have realized handsomely from the speculative enterprise. The community has been gutted of its principal capital. It has lost the basis for industry and has now only unproductive land that for many years will be a burden rather than a source of prosperity. This is not an occasional occurrence. It is the history of millions of acres of land unproductive and now an economic desert.

\section{PRIVATE FORESTRY MUST SUPPLEMENT PUBLIC FORESTRY.}

I am advocating a large program of public forests widely distributed throughout the country; but the solution of the forest problem will not come from public forests alone. Even with the most liberal policy of acquiring additional public forests, the Nation's needs with respect to forests in the future will have to be met in considerable part from private lands. We point to the forests of France as having met a great crisis in the war. Do you know that 60 per cent of the American supplies obtained in France came from private forests?

You may ask if the increasing interest in forestry of private owners and the operation of State forest laws are not likely to bring greatly changed conditions in the near future. Unfortunately this will not be the case unless a much more comprehensive and effective program is adopted by the public and there is a radical change in point of view and methods on the part of most timberland owners. We should give credit to those individual owners and groups who are endeavoring to handle their timberlands constructively. Great credit, too, is due to the State foresters and their supporters for what they have achieved in the face of public indifference and even hostility. But when we consider our forests as a whole we have hardly begun to stem the tide of forest destruction. Even in the matter of organized fire protection the effort on private lands is confined chiefly to the protection of the merchantable timber. Cut-over lands and young tree growth are usually not protected except as may be necessary to safeguard the mature timber; and over a great part of the country there is practically no effort whatever to keep out fires.

Timberland owners feel that they can not change their present methods. They have purchased the land to exploit the timber and not to grow a new crop of trees. For an owner who intends to hold his lands, forestry is just as essential as is agriculture to a farmer. But most timberland owners do not intend to hold their lands after cutting the timber; and they see no reason why they should expend money 
or effort on the land to secure public benefits or to avoid injury to the community. It is the speculative character of ownership that explains the lack of incentive to timberland owners to handle their lands constructively. And we may not expect that such owners will take any different view or action on their own initiative. The profits of forestry, though very real, do not furnish in themselves a sufficient incentive to cause the change.

\section{A CONSTRUCTIVE PROGRAM FOR PRIVATE FORESTRY.}

In seeking a solution for the forestry problem on private lands, it should be recognized that its very character is such as to require public participation, assistance, and direction. There are certain things that the public should do, and in a liberal spirit, to make forestry by private timberland owners possible and effective. At the same time the public should insist by adequate legislation that the destructive processes be stopped, and that methods be adopted which will leave the forests in a productive condition. To secure these ends there is necessary a broad program that is practicable and equitable, based on consideration of existing economic conditions. Its formation calls for the most careful constructive thought, with no point of view neglected.

The limits of this paper do not permit the discussion of all the problems that must be considered in an effective program of forestry on private lands. Some principles may, however, be briefly indicated. A program of forestry should include, first of all, compulsory fire protection; and this should apply to second growth and cut-over lands as well as to old timber. State laws should be unequivocal, with adequate penalties, in their requirements upon timberland owners for protective measures, including the prevention of dangerous accumulations of slashings. Fire protection should be organized and under State supervision. The States should provide an effective organization to enforce the fire laws and to administer the organized protective work. Liberal funds should be made available for patrol, improvements, supervision, and inspection. In most of the States the laws are not drastic enough; there is not sufficient direct responsibility on the owner, and there are not provided adequate means to execute the laws and administer the protective work. The damage by forest fires can be stopped. Its continuance is due to a combined failure on the part of the public and the owners.

The methods of cutting determine whether for one or perhaps several tree generations the lands will be productive or not. The public in its own protection should prohibit destructive methods of cutting that injure the community and the public at large. With the cooperation of the public, constructive measures of forestry are feasible. They should be mandatory. 
The States should adopt a policy of taxation of forests that would encourage rather than hinder the practice of forestry. Present tax policies tend to force early cutting and add to the burden of holding young forestș.

Other factors also cause premature and wasteful cutting in most timberland regions. The speculative character of ownership, the burdens of carrying stumpage, the necessity to meet the interest on borrowed capital and other fixed charges, and the uncertainties regarding markets, labor, and other conditions are among the causes of the haste to cut. The result is frequent overproduction, demoralization of the market, and industrial instability. Lumbermen are already appealing to the public to aid them to bring about a more stable condition of the industry. They have requested tax reforms, the naming by the Government of "fair prices," based on cost of production, and the modification of the Sherman act to permit agreements, in restraint of trade, for the curtailment of production.

The industrial situation is one that demands the consideration of the public, because of the many. public interests involved, including the danger to our remaining forests. I do not concur in the proposals that have been made for Federal legislation relative to agreements in restraint of trade, but I believe that public participation is necessary to meet the difficulties. The solution of this problem involves many features that can be taken care of by improvements within the industry itself; others require public cooperation to bring about a sounder basis of ownership and financing of timberlands. In any case, aid extended by the public should carry with it an insistence that the forest lands be handled constructively, from the standpoint both of protection and of forest growth. In fact, the very measures that would be necessary to secure a right handling of forest lands would go far in solving the problem of instability that constantly menaces the lumber industry and all the interests dependent upon it.

A program of forestry should include, further, cooperation in problems of labor, in land classification looking to the development of agricultural portions of cut-over lands, cooperation in colonization, public activities in technical and economic research, cooperation in the methods of forestry, and so on.

The farm woodlot offers a special problem. The public should lend liberal assistance to the farmer and the small owners, not only in demonstrating the best methods of forestry and in reforestation but also in matters which pertain to marketing the products of the woodlot.

Finally, a program of private forestry is intimately related to that of public forests. We should greatly extend our public forests. Forests on critical watersheds should be owned by the public for their 
protective value. Public forests serve also as centers of cooperation with private owners and as demonstration areas for the practice of forestry as well as furnishing direct benefits in producing wood materials, as recreation grounds, etc.

\section{NEED OF ACTION.}

We have been discussing these problems for many years, but we have made little progress in securing the right handling of private lands. The need of the general public to have the forest lands of the country productive and the need of wood-consuming imdustries alike call for the initiation of a broad program of forestry that includes private as well as public forests. I have presented some of the issues as I see them. I urge that those interested in the forest problem join in bringing about some definite and conclusive action.

\section{ADDITIONAL COPIES}

07 THIS PUBLICATION MAY BE PROCURED FRO

THE SUPERINTENDENT OF DOCUMENTS GOVERNMENT PRINTING OFTICE WASHINGTON, D. C.

b CENTS PER COPY 


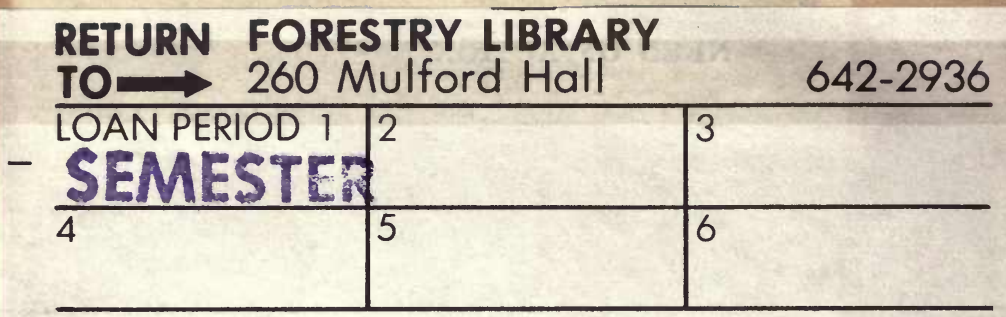

ALL BOOKS MAY BE RECALLED AFTER 7 DAYS

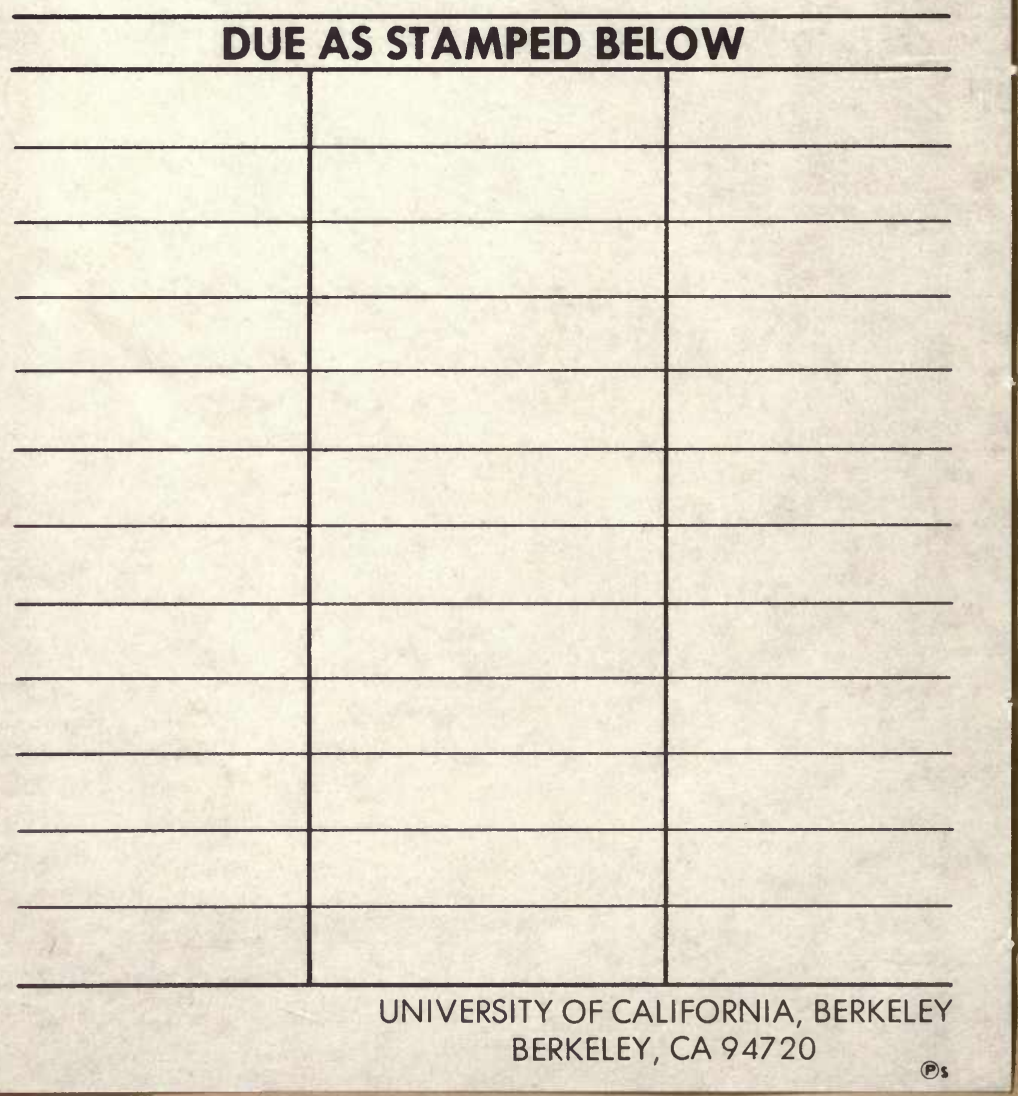


